\title{
New fossil species of Trichodesma LeConte, 1861 (Coleoptera: Ptinidae) from Eocene Baltic amber collected in the Kaliningrad region, Russia
}

\author{
Andris Bukejs, Jiří Háva, and Vitalii I. Alekseev
}

\begin{abstract}
Based on a well-preserved specimen from Eocene Baltic amber (Kaliningrad region, Russia), Trichodesma fennosarmatica sp. nov. is described and illustrated. It is the fourth fossil species of this genus. The new species is similar to the extinct Trichodesma electra Zahradník and Háva, 2017, T. groehni Zahradník and Háva, 2017, and T. amberica Zahradník and Háva, 2017 from Baltic amber, but differs in the number of elytral tufts of erect setae that are present. A key to fossil species of Trichodesma is provided.
\end{abstract}

Andris Bukejs. Institute of Life Sciences and Technologies, Daugavpils University, Vienības Str. 13, Daugavpils, Latvia. carabidae@inbox.Iv

Jiří Háva. Department of Forest Protection and Entomology, Faculty of Forestry and Wood Sciences, Czech University of Life Sciences, Kamýcká 1176, CZ-165 21, Prague 6 - Suchdol, Czech Republic. jh.dermestidae@volny.cz

Vitalii I. Alekseev (corresponding author). Department of Zootechny, Kaliningrad State Technical University, Sovetsky avenue 1.236000, Kaliningrad, Russia. alekseew0802@yahoo.com

Keywords: Anobiinae; death-watch beetle; fossil resin; Paleogene; Tertiary; new species

Submission: 4 January 2018 Acceptance: 2 April 2018

\section{INTRODUCTION}

The genus Trichodesma LeConte, 1861 contains 68 extant species and is distributed in the southern and southwestern Nearctic, Neotropical, eastern Palaearctic, Afrotropical and northern
Indomalayan regions (Español, 1966; White, 1982; Peck, 2005; Sakai, 2005; Viñolas and Masó, 2007; Zahradník, 2007; Zahradník and Háva, 2014b). Three fossil species of this genus have been described from Baltic amber (Zahradník and Háva, 2017) until now. In the present paper, the study of

http://zoobank.org/590DB04F-4DDA-49ED-BFA9-92AA86937A93

Bukejs, Andris, Háva, Jiří, and Alekseev, Vitalii I. 2018. New fossil species of Trichodesma LeConte, 1861 (Coleoptera: Ptinidae) from Eocene Baltic amber collected in the Kaliningrad region, Russia. Palaeontologia Electronica 21.2.17A 1-7. https://doi.org/10.26879/ 848

palaeo-electronica.org/content/2018/2179-new-fossil-trichodesma

Copyright: May 2018 Paleontological Society.

This is an open access article distributed under the terms of Attribution-NonCommercial-ShareAlike 4.0 International (CC BY-NC-SA 4.0 ), which permits users to copy and redistribute the material in any medium or format, provided it is not used for commercial purposes and the original author and source are credited, with indications if any changes are made.

creativecommons.org/licenses/by-nc-sa/4.0/ 
the Ptinidae paleofauna of this Lagerstätte is continued (Quiel, 1909; Abdullah and Abdullah, 1967; Kuśka, 1992; Bellés and Vitali, 2007; Hawkeswood et al., 2009; Alekseev, 2012, 2014; Zahradník and Háva, 2014a, 2017; Bukejs and Alekseev, 2015; Bukejs et al., 2017), and a new species from Baltic amber is described. A key to the described Trichodesma species from Baltic amber is provided in Appendix 1.

\section{MATERIAL AND METHODS}

The material examined is currently housed in the private collection of Christel and Hans Werner Hoffeins, Hamburg, Germany $(\mathrm{CCHH})$, and the holotype (current number $\mathrm{CCHH}$ 1771-1) will be placed in the Senckenberg Deutsches Entomologisches Institut under the number SDEI Coleoptera \# 301525, as part of the institute's amber collection. The amber piece was prepared manually and covered with polyurethane lacquer to avoid oxidation. Observations of this specimen were made using a Nikon® SMZ 745T stereomicroscope. The photographs were taken using a Nikon ${ }^{\circledR}$ SMZ 745T stereomicroscope equipped with a Nikon ${ }^{\circledR}$ DSFi1 digital camera. Extended depth of field at high magnifications was achieved by combining multiple images from a range of focal planes using Helicon Focus 6.0.1 software. Measurements were taken using an ocular micrometer on a stereomicroscope (and these are expressed in millimeters).

The type specimen of the species described herein has been provided with a red, printed label: "HOLOTYPE Trichodesma fennosarmatica sp. nov. Bukejs, Háva and Alekseev det. 2018".

\section{SYSTEMATIC PALAEONTOLOGY}

Family PTINIDAE Latreille, 1802

Subfamily ANOBIINAE Fleming, 1821

Tribe NICOBIINI White, 1982

Genus TRICHODESMA LeConte, 1861

Note. The specimen considered here was assigned to the genus Trichodesma within the tribe Nicobiini based on a combination of the following morphological characters: (1) body dorsal surface with tufts of erect setae; (2) tarsal claws with wide, basal tooth.

Trichodesma fennosarmatica sp. nov.

Figures 1.1-3, 2.3-4

zoobank.org/AD862819-AAD2-4788-9962-E3BA4A531FDA

Type material. Holotype: No. 1771-1 (CCHH), adult, sex unknown. Complete beetle included in small, transparent, yellow amber piece with dimen- sions of $11 \times 8 \times 5 \mathrm{~mm}$. Syninclusions consist of a female Dolichopodidae (Diptera), plant trichomes (stellate hairs), many small pieces of organic material, and few gas vesicles.

Type strata. Blue Earth layer, Baltic amber, Middle Eocene to Upper Eocene.

Type locality. Yantarny settlement (formerly Palmnicken), Sambian (Samland) Peninsula, the Kaliningrad region, Russia.

Etymology. The specific epithet "fennosarmatica" is formed after the word Fennosarmatia, the palaeogeographical amberiferous Eocene continental area, uniting the present-day Fennoscandia and East European plain.

Differential diagnosis. The new species differs from fossil Trichodesma electra Zahradník and Háva, 2017, T. groehni Zahradník and Háva, 2017 and T. amberica Zahradník and Háva, 2017 in number of elytral tufts (see key in Appendix 1).

Description. Body length ca. $6.2 \mathrm{~mm}$; body shape elongate, subcylindrical; body color reddish dark brown, with appendages slightly paler in color. Pronotum and elytra with setation of two types: (1) short, dense, white subrecumbent pubescence, and (2) long, sparse, brown erect setae. Head with short, sparse, subrecumbent setae; ventral surface densely covered with short, white recumbent pubescence. Pronotum with tuft of erect reddishbrown setae. Each elytron apparently with six weak, short, longitudinal tufts of erect reddishbrown setae: three tufts present in apical onefourth of elytral length, two tufts present on elytral disc (near elytral suture), and one indistinct tuft located near humerus.

Head hypognathous, evenly convex; frons with sparse, fine punctures; vertex with dense, small granules, and interspaces between granules smaller than diameter of one granule. Compound eyes small, oval, convex, entire, with distinct facets, without ommatidial setae; distance between compound eyes nearly equal to $2 x$ vertical diameter of one eye. Last labial palpomere triangular with widened apex, anterior margin bisinuate. Antennae almost not visible in examined specimen; apical antennomere elongate, nearly spindle-shaped, penultimate antennomere slightly dilated apically, about $0.6 x$ length of apical antennomere. Antennal insertions widely separated; interantennal distance equal to $0.75 x$ width of frons.

Pronotum convex medially, with large bump in middle; densely granulated (with granulation near posterior margin distinctly sparser), distance between granules equal to $0.3-1.2 x$ diameter of one granule. 

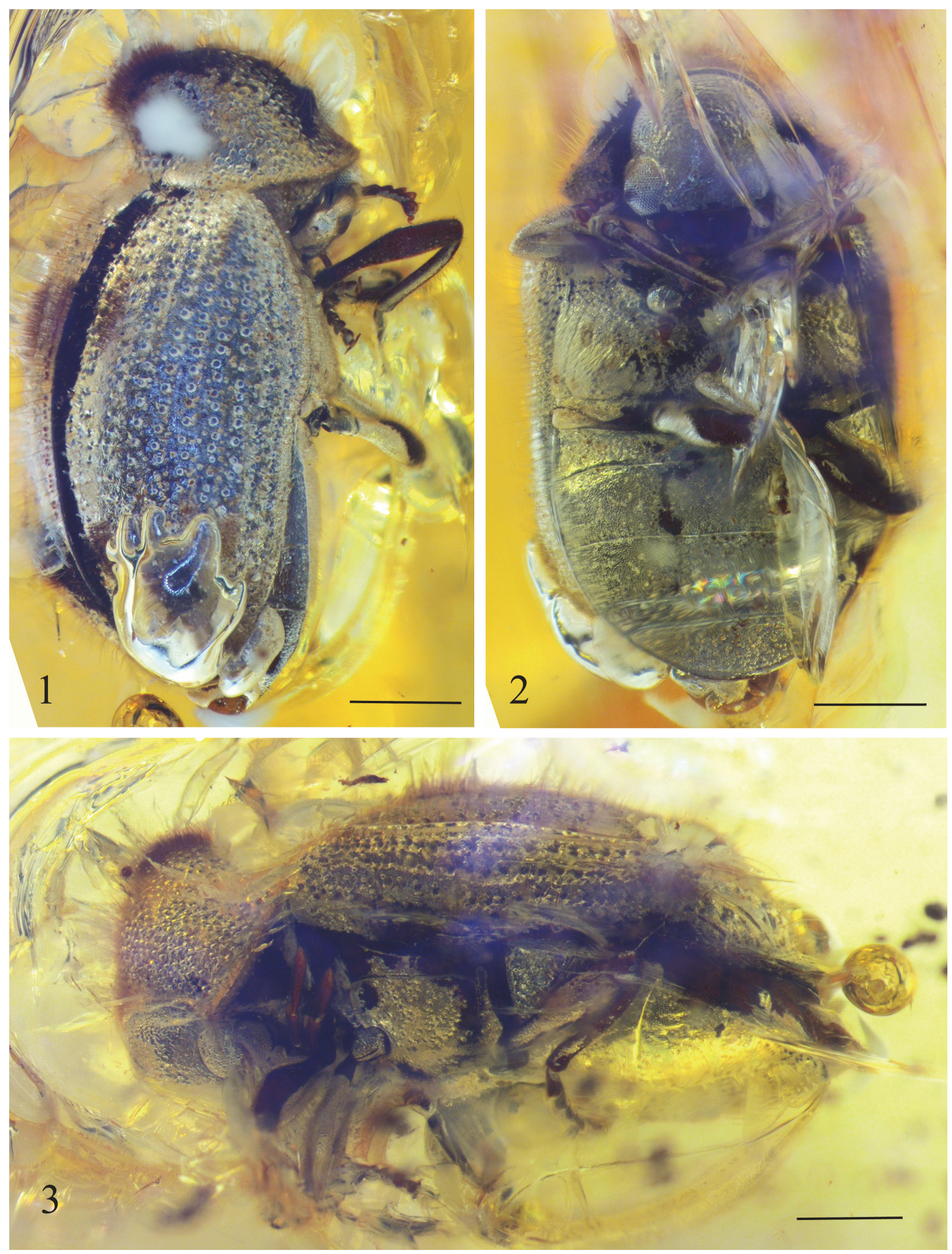

FIGURE 1. Photographs of Trichodesma fennosarmatica sp. nov. (holotype, No. 1771-1 [CCHH]) habitus in dorso-lateral (1), ventral (2), and left lateral (3) views. Body length is ca. $6.2 \mathrm{~mm}$. Scale bar equals $1 \mathrm{~mm}$. 

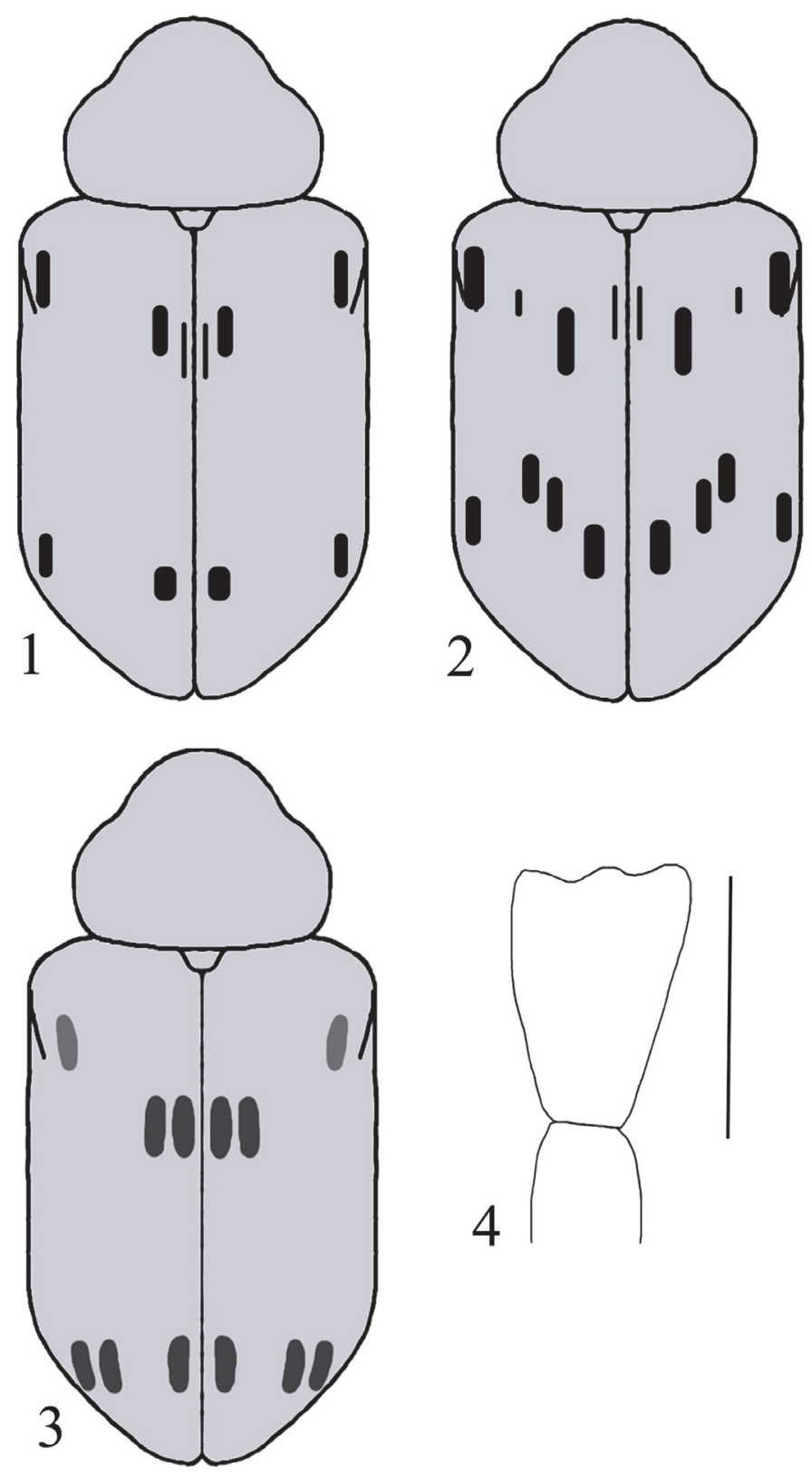

FIGURE 2. 1-3, Schematic illustrations showing difference in the location of elytral tufts in three Trichodesma species known from Baltic amber: T. groehni Zahradník and Háva, 2017 (1), T. electra Zahradník and Háva, 2017 (2), and T. fennosarmatica sp. nov. (3); and 4, a line drawing of the apical labial palpomere of T. fenosalmatica sp. nov. (holotype, No. 1771-1 [CCHH]) in dorsal view. Scale bar equals $0.2 \mathrm{~mm}$.

Scutellar shield triangular, large, transverse. Elytra subparallel, elongate, with humeral calli well developed. Elytral punctures round, dense, moderately large, arranged in striae; striae distinct throughout entire length of elytron, distance between strial punctures equal to $0.5-1.5 x$ diameter of one puncture; interstrial intervals convex; dis- tance between striae about 2.0-2.5x diameter of one strial puncture.

Epipleura with sparse, long, erect setae and dense granulation; wide near humeri and gradually narrowing toward elytral apex, but not reaching elytral apex. Hypomera and metasternum with moderately sparse, small granules. Abdomen with five 
visible ventrites, with sparse, small granulation. Relative length ratios of ventrites 1-5 (medially) equal to 18-30-25-10-23.

Legs short and moderately robust. Mesocoxae globose, distinctly separated. Metacoxae elongate, transverse, widely separated; metacoxal plaques short, subtriangular with rounded apex. Trochanters subglobous. Femora and tibiae almost equal in length; femora clavate, ventrally with longitudinal groove for reception of tibiae; tibiae straight, not widened apically. Tarsal formula: 5-5-5. Tarsomeres 1-2 transverse, short, subequal in length; tarsomeres 3-4 deeply lobed, strongly transverse; tarsomere 5 large, about as long as tarsomeres 34 combined, widened apically, nearly as long as wide. Relative length ratios of mesotarsomeres 15 (medially) equal to 7-6-10-9-18. Tarsal claws long, with large, wide tooth basally.

\section{DISCUSSION}

Several ecological inferences can be drawn on the basis of the fossil species diversity of Trichodesma in Baltic amber, when compared to the recent biology of the genus. Various hardwood trees have been reported as hosts for many members of Trichodesma in North America (White, 1982), some of these trees are: Carya, Lindera, Benzoin, Nyssa, Persea, and Liquidambar. In con- trast to a majority of the described Baltic amber anobiine beetles (conifer specialists like Microbregma; or taxa associated with many different trees, like Hemicoelus), the diverse Trichodesma representatives provide strong evidence for the presence of a rich, deciduous, warm-temperate flora in the Eocene Baltic forests. The recently published analyses of the Baltic amber plant assemblage (Alekseev and Gnilovskaja, 2016; Ignatov et al., 2016; Sadowski et al., 2017a, 2017b) complement the interpretation that is forming as a result of studies on insect inclusions. Plant inclusion data, combined with the data that has been accumulated in the last few decades, on the assemblages and paleoecology of phytophagous and xylophagous beetles, is building toward a significant advance in the understanding of the Eocene amber ecosystem.

\section{ACKNOWLEDGEMENTS}

The authors are sincerely grateful to $\mathrm{Ch}$. and H.W. Hoffeins (Hamburg, Germany) for the loan of fossil material from their great private collection and for the determination of the Diptera syninclusion. Three anonymous reviewers are greatly appreciated for their valuable comments and corrections.

\section{REFERENCES}

Abdullah, M. and Abdullah, A. 1967. Crictonia macleani, a new genus and species of the Hedobiini (Coleoptera, Anobiidae) from the Baltic amber. Entomological News, 28:23-27.

Alekseev, P.I. and Gnilovskaja, A.A. 2016. The diversity of Pinaceae pollen cones from Baltic amber (Late Eocene). Palaeobotany, 7:47-55. (In Russian)

Alekseev, V.I. 2012. Sucinoptinus bukejsi sp. nov. (Coleoptera: Ptinidae: Ptinini), the second species of the Tertiary genus from the Baltic amber. Baltic Journal of Coleopterology, 12:145148.

Alekseev, V.I. 2014. New fossil species of Ptinidae (Insecta: Coleoptera) in Baltic amber (Tertiary, Eocene). Zoology and Ecology, 24:239-255. https://doi.org/10.1080/21658005.2014.909154

Bellés, X. and Vitali, F. 2007. New fossil spider beetles from Baltic amber (Coleoptera Ptinidae). Entomapeiron (P.S.), 2:17-28.

Bukejs, A. and Alekseev, V.I. 2015. A second Eocene species of death-watch beetle belonging to the genus Microbregma Seidlitz (Coleoptera: Bostrichoidea) with a checklist of fossil Ptinidae. Zootaxa, 3947(4):553-562. https://doi.org/10.11646/zootaxa.3947.4.6

Bukejs, A., Alekseev, V.I., Cooper, D.M.L., King, G.A., and McKellar, R.C. 2017. Contributions to the palaeofauna of Ptinidae (Coleptera) known from Baltic amber. Zootaxa, 4344(1):181-188. https://doi.org/10.11646/zootaxa.4344.1.12

Español, F. 1966. Notas sobre anóbidos (Coleoptera). XVII. Las Trichodesma del África tropical. Eos, 41(2-3):215-222.

Fleming, J. 1821. Insecta. p. 41-56. In Napier, M. (ed.), Supplement to the Fourth, Fifth and Sixth Editions of the Encyclopaedia Britannica. Vol. 5. Part 1. A. Constable and Company, Edinburgh. 
Hawkeswood, T.J., Makhan, D., and Turner, J.R. 2009. Anobium jacquelinae sp. nov., a new wood-boring beetle (Coleoptera: Anobiidae) from Baltic amber. Giornale Italiano di Entomologia, 12:181-187.

Ignatov, M.S., Abakarova, A.S., Alekseev P.I., and Kučera, J. 2016. Cynodontium eocenicum, a new moss from the Baltic amber. Arctoa, 25:236-240.

Kuśka, A. 1992. Three new species of beetles (Coleoptera: Cantharidae, Anobiidae, Curculionidae) from the Baltic amber. Annals of the Upper Silesian Museum-Entomology, 3:107-113.

Latreille P.A. 1802. Histoire naturelle, génerale et particuliere des crustacés et des insectes. Ouvrage faisant suite aux oeuvres de Leclerc de Buffon, et partie du Cours complet d'Histoire naturelle rédigé par C. S. Sonnini, membre deplusieurs Sociétés savantes. Tome troisiěme. F. Dufart, Paris.

LeConte, J.L. 1861. Classification of the Coleoptera of North America. Prepared for the Smithsonian Institution. Part I. Smithsonian Miscellaneous Collections, 136:1-214.

Peck, S.B. 2005. A Checklist of the Beetles of Cuba with Data on Distributions and Bionomics (Insecta: Coleoptera). Arthropods of Florida and Neighboring Land Areas. Vol. 18. Florida Department of Agriculture and Consumer Services, Gainesville.

Quiel, G. 1909. Zwei neue Coleopteren aus dem baltischen Bernstein (Eozän bezw. unteres Oligozän). Berliner Entomologische Zeitschrift, 54:49-52.

Sadowski, E.-M., Schmidt, A.R., Seyfullah, L.J., and Kunzmann, L. 2017a. Conifers of the 'Baltic amber forest' and their palaeoecological significance. Stapfia, 106:1-73.

Sadowski, E.-M., Seyfullah, L.J., Wilson, C.A., Calvin, C.L., and Schmidt, A.R. 2017b. Diverse early dwarf mistletoes (Arceuthobium), ecological keystones of the Eocene Baltic amber biota. American Journal of Botany, 104 (5):694-718. https://doi.org/10.3732/ajb.1600390

Sakai, M. 2005. Trichodesma michioi (Coleoptera, Anobiidae, Anobiinae), a new anobiid species from the Ryukyus, Japan. Elytra, 33 (1):42-46.

Viñolas, A. and Masó, G. 2007. Nuevas especies de los géneros Trichodesma LeConte, 1861 y Gastrallus Jacquelin du Val, 1860, del África Austral (Coleoptera, Anobiidae). Animal Biodiversity and Conservation, 30(1):53-70.

White, R.E. 1982. A Catalog of the Coleoptera of America North of Mexico. Family Anobiidae. U.S. Department of Agriculture, Washington, D.C.

Zahradník, P. 2007. Ptinidae (without Gibbiinae and Ptininae), p. 339-362. In Löbl, I. and Smetana, A. (eds.), Catalogue of Palaearctic Coleoptera. Elateroidea - Derodontoidea Bostrichoidea - Lymexyloidea - Cleroidea - Cucujoidea. Volume 4. Apollo Books, Stenstrup.

Zahradník, P. and Háva, J. 2014a. New Ptinidae (Coleoptera: Bostrichoidea) from Baltic amber with a list of known fossil species. Studies and Reports, Taxonomical Series, 10(2):629-646.

Zahradník, P. and Háva, J. 2014b. Catalogue of the world genera and subgenera of the superfamilies Derodontoidea and Bostrichoidea (Coleoptera: Derodontiformia, Bostrichiformia). Zootaxa, 3754(4):301-352. https://doi.org/10.11646/zootaxa.3754.4.1

Zahradník, P. and Háva, J. 2017. Three new species of Trichodesma LeConte, 1861 from Baltic amber (Coleoptera: Ptinidae: Anobiinae). Folia Heyrovskyana, Series A, 25(1):89-92. 


\section{APPENDIX 1.}

Key to extinct species of Trichodesma (modified from Zahradník and Háva, 2017).

(1) Elytra without tufts of erect setae. Body length $4.8 \mathrm{~mm}$.

Trichodesma amberica

- Elytra with tufts of erect setae

(2) Each elytron with 8 tufts of black, erect setae (Figure 2.2).

Body length $6.9 \mathrm{~mm}$.

Trichodesma electra

- Each elytron with less than 8 tufts of erect setae

3

(3) Each elytron with 5 tufts of black, erect setae (Figure 2.1).

Body length $4.2 \mathrm{~mm}$

Trichodesma groehni

- Each elytron with 6 tufts of reddish-brown, erect setae (Figure 2.3).

Body length $6.2 \mathrm{~mm}$ Trichodesma fennosarmatica sp. nov. 